\title{
STUDIES OF INHERITANCE AND EVOLUTION IN ORTHOPTERA I.
}

\author{
By ROBERT K. NABOURS.
}

Paper 3. From the Zoological Laboratory, IKansas State Agricultural College.

CONTENTS.

I. Introduction

II. Material and Method .

III. Analyses of gametic constitutions and the inheritance of colour patterns .

(1) An analysis and the inheritance of the colour patter'ns of forms of the appearance of texanus, leuconotus, leticothorax and punctofemorata

(2) An analysis and the inheritance of the colour patterns of forms of the appearance of luteolineatus and rufrolineatus . . 150

(3) The interbreeding of heterozygotes . . . . . . . . 155

(4) Further hybridization and the inbreeding of the heterozygotes . 157

(5) Results from the mating of heterozygotes with one or the other of the parent forms . . . . . . . . . 159

IV. Long and Short wingedness . . . . . . . . . . 160

(1) Long and short wingedness in nature . . . . . . . 160

(2) Long and short wingedness in the breeding experiments . . 162

V. An examination of the location, alrangement and relations of the pigmental elements in the colour patterns of the parent forms and their hybrids . . . . . . . . . . . 164

VI. Discussion . . . . . . . . . . . . . . . . 166

(1) The inheritance of the colour patterns . . . . . . . 166

(2) The appearance of long and shor't wingedness . . . . . 167

(3) Equivalence in the hybrids . . . . . . . . 168

(4) The "genotype conception" applied to the behavioul' of these forms 168

VII. Conolusions . . . . . . . . . . . . . . 169

Bibliography . . . . . . . . . . . . 170

Journ. of Gen. III 10 


\section{IN'TRODUCTION.}

THe well-known experiments of Mendel, and the work of the NeoMendelians with numerous plants and animals, show clearly that surprisingly exact predictions of the results of breeding can be made, provided the gametic constitutions of the parents are known, furthermore the gametic constitution of the parents can also be determined by breeding analyses. That there is segregation, or altemativeness, in gametogenesis which accounts for the familiar Mendelian ratios is a generalization which now seems to be well established. However, even in this matter there are some apparently important exceptions which engender doubt in the minds of some persons.

The existence of unit characters, in the De Vriesian sense, does not appear to have been as clearly demonstrated as that of alternative inheritance, and if one may judge from expressions of opinion concerning this matter, the interpretations are at great variance. Thus one group of authors recognize characters in organisms that can be replaced by other characters, when the proper crosses are madea clear recognition of separable and replaceable characters, which are not necessarily unit characters $(1,3,8)$-while on the other side there are those who believe that the organism as a whole is the only unit and that there are no actual unit characters $(9,7)$.

In this paper is presented a preliminary account of an experimental inquiry into the problems of inheritance and evolution, which is now being carried on with several species of the grouse-locusts (Tetriginae) of the genus Paratettix, Bolivar.

\section{MATERIAL AND MESHOD.}

The Tetriginae are widely distributed, and are principally distinguished from other nearly related Orthoptera by the pronotum which extends backwards over the body and wings, a character which varies greatly among the different genera. The North American genera are mostly geophilous, live on damp earth covered with algae, especially in moist meadows and woods, and on the margins of ponds and streams (4). The genus Paratettix, Bol., is distributed over a large part of the United States and Mexico, and the species therein are mainly distinguished by their striking colour patterns. 
I have collected in the Mississippi Valley and on the Gulf Constal Plain of Louisiana and Texas nine distinct true breeding forms of this genus which are being used in the breeding experiments (Plate VI, figs. 1-9). There seems to be uncertainty as to the taxonomic position to be given these forms. It has been suggested that they be called varieties and again that they be designated as biotypes, and, with best reason, it seems to me, that they be called species outright. Pencling. further consideration of this matter; it seems sufficient for the purposes of this paper to give them names descriptive of the colour patterns, leaving to the future the question as to whether or not these designations are to become the specific names of the forms. However, the names will be tentatively submitted as though they are the specifie ones of the genus Paratettix, Bol., the taxonomic position which I believe will eventually be accorded them. The nine forms, all of them new, except one, are as follows: Paratettix texanus, Hanc. (Plate VI, fig. 1); $P$. leuconotus, n. sp. (fig. 2); P. leucothorax, n. sp. (fig. 3); $P$. punctofemoratu, n. sp. (fig. 4); P. luteolineatus, n. sp. (fig. 5); P. rufrolineatus, n. sp. (fig. 6); P. melanothorax, n. sp. (fig. 7); $P$. luteonotatus, n. sp. (fig. 8); and $P$. nigronotatus, n. sp. (fig. 9). A more detailed taxonomic description of these and several other forms used and something of their habits will be presented in a separate account.

The characters used in this investigation have been the colour patterns of the pronota and of the femora of the jumping legs (Plate $\mathrm{VI}$ ), and the length of the pronotum and wings, whether short, intermediate, or long (Fig. 2, p. 161). The final colour pattern is clearly indicated soon after the moult which ushers in the second instar; and there are no perceptible changes in it during the remainder of the life of the individual. Thes wing and pronotum lengths cannot be determined until the individual becomes adult, and are not in any way correlated with the colour patterns. The forms and their hybrids interbreed freely, and reciprocal crosses have invariably produced identical results. All the females used in the experiments recorded here were virgin, excepting the two heterozygous texinus-leucothorax females from nature used in the beginning of Exp. I (p. 145).

Glass cylinders, $8^{\prime \prime} \times 12^{\prime \prime}$ and $9^{\prime \prime} \times 15^{\prime \prime}$ respectively, set in pots of earth and covered with 12 - or 24 -mesh pearl wire, seem to make the most convenient cages (Fig. 1). It is found best to overlay, the surface of the earth in the cages with a very rich vegetable mould, or peat substance. The smaller cages covered with the 12 -inch mesh wire are 


\section{Inheritance and Krolution in Orthoptera I}

used as breeding cages. Soon after the young hatch, they are transferred by means of a damp camel hair brush to the larger cages covered with the 24-mesh wire. The best food found consists of the green scrapings (algae, lichens, etc.) from the long used pots holding hothouse plants, though the various filamentous algae serve very well. The mortality on the whole is great.

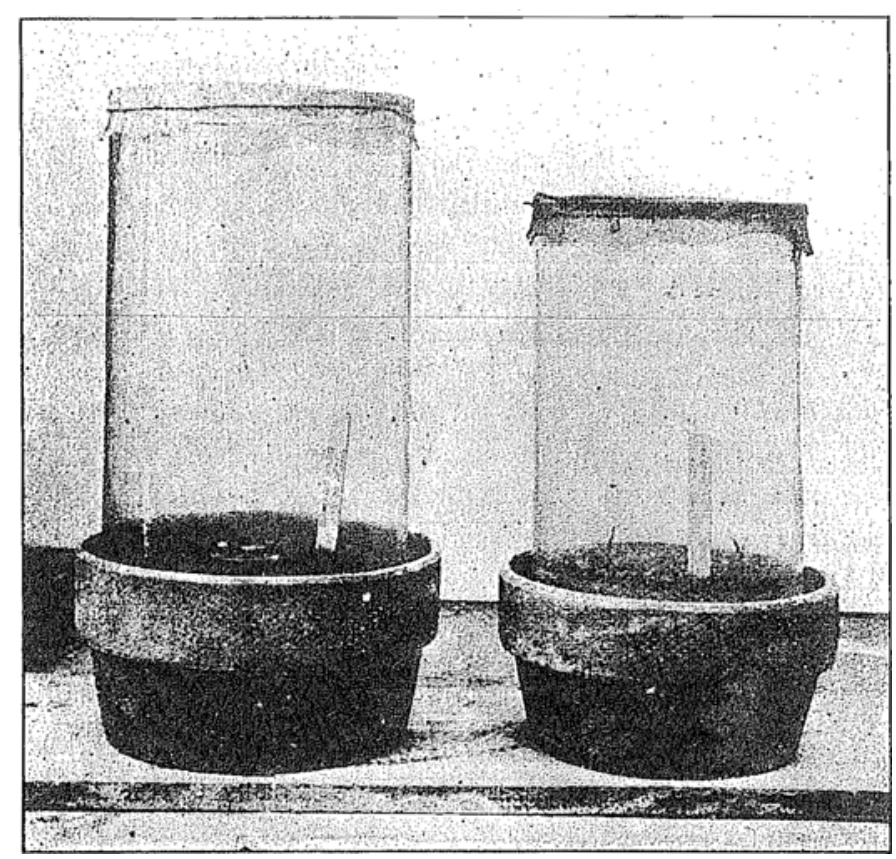

Fig. 1.

\section{IIT. Analyses OF Gametic CONSTItUTHONS AND THE INHERITANCE OF COLOUR PATTERNS.}

(1) An analysis and the inheritance of the colour patterns of forms of the appearance of texanus, leuconotus, leucothorax, and punctofemorata.

For convenience, the homozygous forms and their gametes will be designated by symbols (letters): texanus by $A$, leuconotus by $B$, leucothorax by $C$, punctofemorata by $D$, luteolineatus by $E$, rufrolineatus by $F$, melanothorax by $G$, luteonotatus by $I$, and nigronotatus by $I$. 
Any two of these lebter's placed side by side will represent the heterozygous, or hybrid zygote, or individual, produced by the union of the homozygous gametes represented by the respective letters.

Farly in September, 1908, specimens of the general appearance of texanus, leuconotus, leucothorax, and punctofemorata (Plate VI, figs. 1-4), were obtained in the vicinity of Houston, Texas. At that time nothing whatever was known of their composition, and the females were not virgin. All the forms were placed in a tin bucket and taken to Chicago. One specimen, a male of the appearance of leuconotus (Plate VI, fig. 2), two specimens, females, of the appearance of leucothorax (Plate VI, fig. 3), and several males and females of texanus and punctofemoratia survived (Plate VI, figs. 1 and 4 ).

Experiment I. On September 12th, the male of the appearnce of lenconotus was mated to the two females of the appearance of leucothoraz (Table I, parents). The progeny which hatched in November and December grew slowly and after great mortality matured in the following March, and showed in $\mathbb{F}_{1}$ five types as follows: 5 of the appearance of lenconotus, 6 leucothorax, 6 intermediate between leuconotus and leucothorax, 12 texanus, and 3 punctofemorata (Table I, $F_{1}^{\prime}$ ). The inbreeding of these $F_{1}$ types, each type to itself, in the $F_{2}$ generation was as follows: two pairs of the lenconotus type were mated in separate cages and gave $F_{2}$ progeny as follows: in cage $(a) 34$ leuconotus $(B)$ and texanus-leuconotus $(A B): 14$ texanus $(A)$, and in cage $(b) 24$ leuconotus $(B)$ and texanus-lenconotus $(A B)$ : 7 texanus $(A)$; the total numbers for the two cages being 59 leuconotus $(B)$ and texanus-leuconotus $(A B): 21$ texanus $(A)$, with the expectation of $60: 20$, respectively. The $F_{1}$ leuconotus-leucothorax $(B C)$ heterozygotes were inbred, as a group culture, and gave in $F_{2}, 66$ leuconotus; 136 leuconotus-lencothorax $(B C)$ : 58 lencothorax, the expectation being $65: 130: 65$, respectively, The $\mathbb{F}_{1}$ leucothorax type inbred, three pairs in separate cages, gave progeny in $F_{2}$ as follows: in cage $(a) 48$ leucothorax and texanus-leucothorax $(A C): 7$ tezsanus $(A)$; in cage $(b)$ 8 leucothorax $(C)$ and texanus-leucothorax $(A C): 10$ texanus $(A)$; and in cage $(c) 66$ lencothorax $(O)$ and texanus-leucothorax $(A C)$ : 15 texanus $(A)$; the total numbers from the three matings being 117 leucothorax $(C)$ and texanus-lencothorax $(A C): 32$ texanus $(A)$, with the expectation of $11175: 3725$, respectively. One of the $\mathbb{P}_{1}$ ponctofemorata type, a male, was mated to a texanus femile, and they gave in $F_{n}, 9$ of the appearance of punctofemorata : 5 texanus. This result shows at least the texanus-punctofemorata $(A D)$ heterozygons 


\section{Inheritance and Evolution in Orthoptera I}

constitution of the $F_{1}$ individuals of the appenrance of punctofemorata. The $F_{1}$ texanus bred true for five generations when the culture was terminated. For a graphic illustration of all these $B_{2}^{\prime}$ resultis compare Table $\mathrm{I}, F_{3}$, and diagram $1, F_{2}$ (p. 151).

At this time, Spring 1909, I was not able to distinguish the pure leuconotus from the hybrid leuconotus-texanus, but since then I have leaned to distinguish between them. On careful exmination, the

TABLE T.

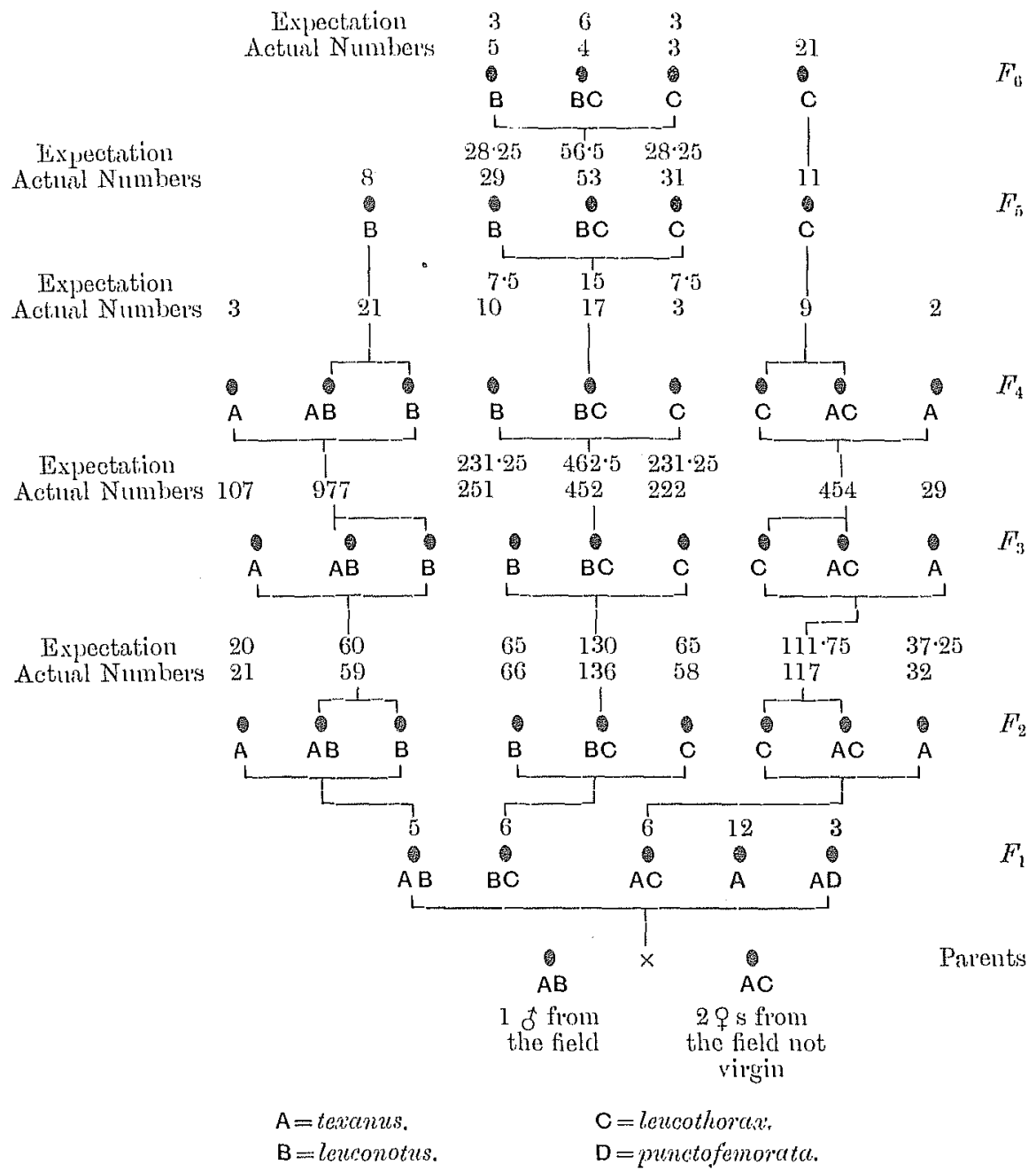


general outlines of the pattern of texanus can be clearly seen in the heterozygote. I am not able to distinguish with certainty between any of the other pure forms and the hybrids between them and texanus; that is, as ordinarily considered, texanus is recessive to all the other species.

An analysis of the $T_{2}$ results just described, with their close approximations to the expected ratios of alternative inheritance, shows that the $F_{1}$ leuconotus were .rozygous, having the gametic constitution $A B$ (allowing $A$ and $B$ to represent the gametes of texanus and lenconotus, respectively). Thi leucothorax in the same way were alss heterozygous, having the composition $A C$ ( $C$ representing lencothornx), and the behaviour of the midtype strikingly points to its heterozygous lenconotus-lencothorax $(B C)$ character. From this behaviour it seems that we may conclude that the parent male from nature was a texanusleuconotus heterozygote of the gametic constitution $A B$, and the females (at least one of them) were texanus-lencothorax $(A C)$ heterozygotes and that some of the eggs of at least one of these females had been fertilized by a pure punctofemorata $(D)$, or heterozygous texanuspunctofemorata $(A D)$ male, and his $D$ gametes meeting her $A$ gametes made the heterozygous texanus-punctofemorata $(A D)$ specimens of the superficial appearance of punctofemorata (Table I, $F_{1}$, and diagram $I F_{1}$ ).

$F_{3}$ results from inbreeding of the $F_{2}$ forms of this series. The leuconotus-leucothorax $(B C)$ inbred, as a group culture, gave in $F_{3}$ 251 leuconotus : 452 leuconotus-leucothorax $(B C): 222$ leucothorax, the expectation being $231 \cdot 25: 4625: 231 \cdot 25$, respectively. The $F_{2}$ generation leuconotus which came from the inbreeding of $F_{1}$ leuconotusleucothorax bred true for three generations and then the culture was destroyed. The $F_{2}$ leucothorax which came from the inbreeding of this $F_{1}$ leuconotus-leucothorax midtype were carried two generations and bred true. The $F_{2}$ forms of the general appearance of leuconotus were inbred in four cages as follows: (a) 1 male $\times 1$ female, $(b) 1$ male $\times 1$ female, (c) 2 males $\times 2$ females, $(d) 2$ males $\times 2$ females. Pair (a) gave 10 leuconotus : 3 texanus; pair (b) gave 275 all leuconotus; pair (c) gave 194 leuconotus : 47 texanus; and pair $(d)$ gave 4.98 lenconotus : 57 texanus. These results are represented graphically in Table I, $F_{3}$, as a group culture, as unfortunately they essentially were, because the main attention at this time was being given to the behaviour of the leuconotus-leucothorax midtype and its products, leuconotus and lencothorax, and to the finding of the proper food and other living conditions. However, the results are suggestive; for in cage (a) 


\section{Inheritance and Evolution in Orthoptera I}

though the numbers are small, the $10: 3$ ratio suggests that the parents were texanus-lenconotus $(A B)$ heterozygotes, since this is a close approximation to the expectation of $975 B$ and $A B: 3.25 A$. In cage $(b)$ one of the parents conld have been of the constitution $A B$ and the other pure $B$, or both could have been pure $B$, becanse at that time, as has already been noted, in making records no distinetion was made between the heterozygous texanus-lenconotis $(A B)$ and the homozygons lenconotus $(B)$. The specimens have been kept preserved in alcohol and although the general outhines of the pattems are still distinct they are not clear enough to permit the fine distinction which would be necessary for selecting the homozygons lenconotns $(B)$ from the heterozygous texanus-leuconotus $(A B)$, as can be done now with the live specimens.

It is obvious that nothing further than that they are $A B$ and $B$ can be ascertained concerning the composition of the parents in cages $(c)$ and $(d)$, though the ratio of 194:47 in cage $(c)$ is suggestive of the expectation of $180^{\cdot 75}: 60 \cdot 25$, if all four of the individuals had been texanus-leuconotus $(A \dot{B})$ heterozygotes. Although the matings were made in such a way as to make the numerical ratios of no value, yet it is to be noted that no unexpected individuals appeared-all were texanus $(A)$, texanus-leuconotus $(A B)$, or leuconotns $(B)$.

The $F_{2}$ impure forms of the appearance of leucothorax were inbred in the same way as were the $F_{2}$ impure lenconotus, i.e., essentially as a group culture. As in the case of the homozygous leuconotus and the heterozygous texanus-leuconotus, I was not able to distinguish between the homozygous leucothorax and the heterozygous texanus-leucothorax. Four group matings were made as follows: (a) 1 male $\times 1$ female; (b) 2 males $\times 2$ females; (c) 2 males $\times 2$ fcmales, and (d) 2 males $\times$ 2 females. The $F_{3}$ results from these matings were as follows: from (a) 259 leucothorax; (b) 65 leucothorax : 11 texanus; (c) 103 leucothorax : 15 texanus; and $(d) 27$ leucothorax : 3 texanus. If none of the leucothorax $F_{3}$ individuals from $(a)$ had been bred further, it would not be known whether the $F_{2}$ parents were both homozygous leucothorax $(C)$, or one of them homozygous $(C)$ and the other heterozygous texanusleucothorax $(A C)$, but 2 males $\times 2$ females were bred and gave in $F_{4}$, after great mortalitiy due to drought in the cage, 9 leucothorax : 2 texanus; thus showing one of the parents in cage $(a), F_{\mathrm{g}}$, to have been undoubtedly heterozygous texanus-leucothorax $(A C)$. The individuals from the other cages were not bred further. It is here again obvious that the composition of each of the parents in these 
cages cannot be ascertained by the appearance of their $F_{3}$ offspring; because 2 males $\times 2$ females were used in each instance. However, no unexpected types appeared, and we do know that the parents were of the two compositions, $C$ and $A C$, and no other than these. The results from the inbreeding of these $F_{2}$ impure lencothorax are shown as a group in Table I, $F_{3}$, and in more detail in diagram $1, F_{3}$.

A group culture of 2 males $\times 2$ females was made from the $F_{2}$ texanus which had come from the $F_{1}$ impure lenconotus and they gave only texanus in $F_{3}$ when the culture was terminated. Similarly, a group culture was made of the $F_{2}$ texanus which had come from the $F_{1}$ impure leucothorax and they bred true in $F_{3}$ when they were also destroyed.

$F_{4}$ results from the separate inbreeding of the $F_{3}$ forms of this series. Several of the $F_{3}$ leuconotus-lencothorax $(B C)$ were inbred, but on account of poor attention, the mortality of the $F_{4}$ progeny was very great. The record of those reaching maturity was 10 leuconotus: 17 leuconotus-leucothorax : 3 leucothorax (Table I, $F_{4}$ ).

From $(d)$, of the texanus-leuconotus $(A B) F_{3}$ group culture, two pairs, a pair each in separate cages, of the appearance of leuconotus were bred. After great mortality the $F_{4}$ result in $(a)$ was 8 leuconotus : 3 texanus, and the pair in $(b)$, gave 13 all leuconotus. These results added together are shown in Table $\mathrm{I}, F_{4}$, as a group culture, giving a $21: 3$ ratio. It appears that the parents in cage $(a)$ were texanusleuconotus $(A B)$ heterozygotes, and that the conge $(b)$ parents were both either homozygous leuconotus $(B)$, or that one of them wis homozygous and the other heterozygous texanus-leuconotus $(A B)$. However, when a pair from cage $(b)$ were bred, they gave in $F_{5}^{\prime}$, 8, all lenconotus in appearance, and this closed the impure leuconotus part of the experiment (Table I, $F_{4}$ and $F_{5}$ ).

From the cage $(a) F_{3}$ progeny, in the impure lencothorax series of this experiment, two males and two females of the appearance of leucothorax were mated as a group culture, and they gave in $F_{4}, 9$ leucothorax : 3 texanus. This result, though small in numbers, shows quite clearly that the pair of the appearance of leucothorax taken from the $(a) F_{2}$ culture and bred to make $(a) F_{3} 259$ all leucothorax in appearance, were not both of them homozygous leucothorax $(C)$, nor were they both heterozygous texanus-leucothorax $(A C)$, but that one of them was a homozygous leucothorax $(C)$, and the other a heterozygous texanusleucothorax $(A O)$, a matter to which attention is given above. The 


\section{Inheritance and Evolution in Orthoptera I}

leucothorax progeny from this $F_{4}$ culture bred true, when inbred, for two generations, giving 11 leucothorax in $F_{s}$ and 21 leucothorax in $F_{6}$ (Table I, $F_{4}, F_{5}$ and $F_{6}$ ).

A pair of texanus from the $F_{4}$ impure leuconotus culture, when bred, gave $100 \%$ texanus, as did a similar pair from the same generation of the impure leucothorax culture. Also a texanus male from the $F_{4}$ texanus-leuconotus culture was mated to a texanus female from the $F_{d}$ texanus-leucothorax culture and they gave $100 \%$ texanus.

The $F_{4}$ leuconotus-leucothorax $(B C)$ were inbred and gave, in $F_{5}, 29$ leuconotus : 53 leuconotus-leucothorax $(B C): 31$ leucothorax, the expectation being 28.25:56.5:28.25, respectively. (Table $I, F_{5}$.)

The $F_{5}$ leuconotus-leucothorax $(B C)$ were again inbred and gave in $F_{6}, 5$ leuconotus : 4 leuconotus-leucothorax $(B C): 3$ leuconotus (Table I, $F_{6}$ ). With this result the experiment was closed.

Allowing the letters $A, B, C$, and $D$, as already suggested, to indicate the homozygous texanus, leuconotus, leucothorax, and punctofemorata, respectively, diagram 1, with Table I, will show at a glance the inheritance behaviour in this experiment.

(2) An analysis and the inheritance of the colour patterns of forms of the appearance of luteolineatus and rufrolineatus.

Experiment IT. Early in September, 1909, among several specimens secured in the vicinity of Many, Lonisiana, were a male of the appearance of rufrolineatus $\left(F^{\prime}\right)$ (Plate VI, fig: 6 ) and an immature female of the appearance of luteolineatus $(E)$ (Plate VI, fig. 5). When the female became adult this male of the appearance of rufrolineatus was mated to her, and their progeny which hatched in November, after great mortality, matured the following March and showed four types in $F_{1}$ as follows: 4 of the appearance of rufrolineatus : 2 intermediate between rufrolineatus and luteolineatus: 2 of the appearance of luteolineatus: 2 texanus (Table II. $(a), F_{1}$ ). These $F_{1}$ progeny were bred further as follows: (a) a pair of the appearance of rufrolineatus were inbred and gave in $F_{2} 43$ of the appearance of the parents (rufrolineatus) : 13 texanus. This shows clearly that the $F_{1}$ individuals of the appearance of rufrolineatus were really texanus-rufrolineatus $\left(A Z^{\prime}\right)$ heterozygotes. This fact, the visibly clear luteolineatus-rufrolineatus $(E F)$ heterozygous character of two others of the $F_{1}$ progeny and the fact that still two others were the always homozygous texanus $(A)$, without considering the two individuals of the appearance of luteolineatus which 
R. K. NABOURS

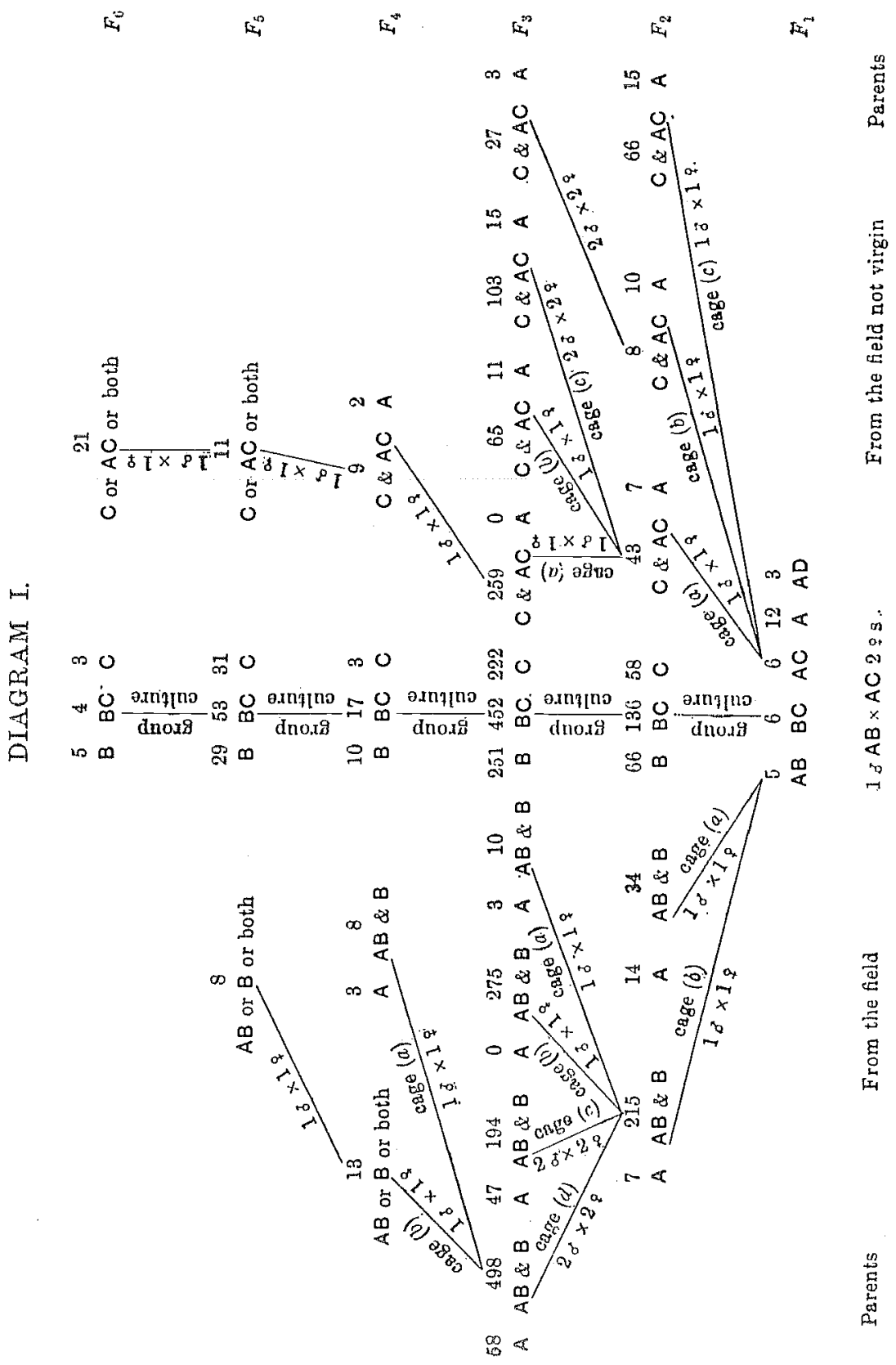


152 Inheritance and Evolution in Orthoptera I

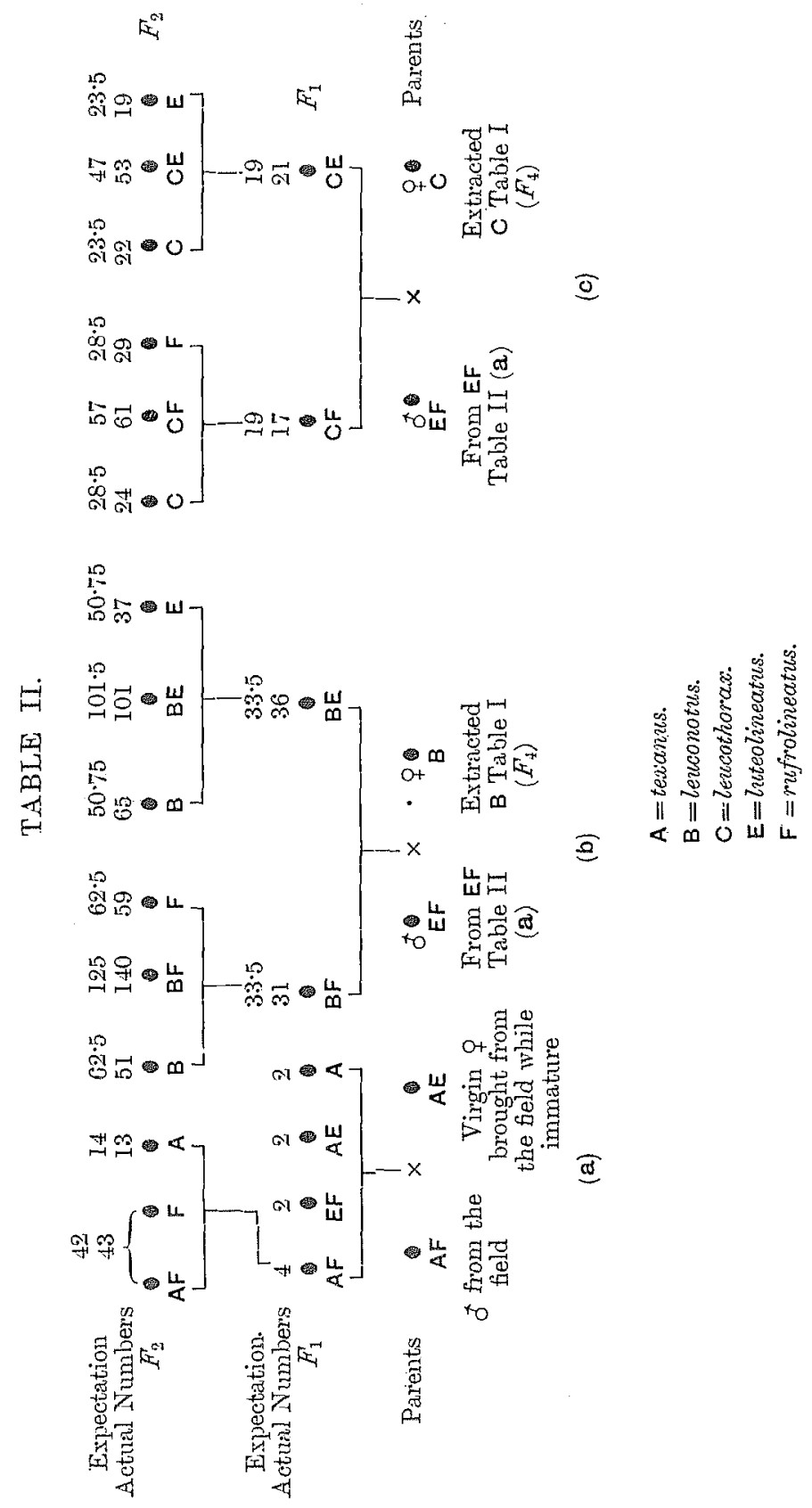


were not bred, all show that the parents fiom nature were really texamus-rufrolineatus $\left(A E^{\prime}\right)$ and texamus-luteolineatus ( $\left.A E\right)$ heterozygotes, respectively. Therefore, the $F_{1}$ progeny should read, texanus-rufrolineatus $(A F)$ 4: huteolineatus rufrolineatus $(E F)$ 2: texanus-huteolineatus $(A E) 2$ : texanus 2 , the expectation being $2 \cdot 25$ of each ('Table II $\left.(a), F_{1}\right)$.

(b) One of the huteolineatus-rufrolineatus $\left(E F^{\prime}\right) F_{1}$ males (Table II $(a) F_{1}$ ) was mated to an extracted homozygous lenconotus $(B)$ female, from a culture whose parentis were both lenconotus-lencothorax $(B C)$ heterozygote (Table I, $F_{4}, B$ ) and they gave $F_{1}$ progeny as follows: leuconotus-rufrolineatus $(B F)$ 31: leuconotus-luteolineatus $(B E)$ 36, the expectation being 33.5 of each kind (Table IT $(b), F_{1}$ ). This result proves unmistakably the huteolineatus-rufrolineatus $(E F)$ heterozygons character of the male parent, supplementing the evidence which the intermediate colour of his stripe had given.

The inbreeding of these lenconotus-rufrolineatus $(B F)$ and lenconotus-huteolineatus $(B E) F_{1}$ individuals, respectively, gave $F_{3}^{\prime}$ results as follows: two pairs of the leuconotus-rufrolineatus $(B F)$ individuals were mated, one pair in each of two cages. The pair in cage $(a)$ gave the following $F_{2}$ progeny: leuconotus 27 : lenconotus-rufrolineatus $\left(B F^{\prime}\right)$ 69 : rufrolineatus 29; and the pair in cage $(b)$ gave lenconotus 24 : leuconotus-rufrolineatus ( $B F$ ) 71 : rufrolineatus 30 ; the two pairs giving totals of 51 leuconotus $(B): 140$ lenconotus rufrolineatus $\left(B F^{\prime}\right): 59$ rufrolineatus $(F)$, with the expectation of $62 \cdot 25: 124 \cdot 5: 62 \cdot 25$, respectively (Table II $(b), F_{2}$ ).

One of these $F_{2}$ rufrolineatus males was mated to a sister lenconotusrufrolineatus female and they gave in $F_{3} 6$ leuconotus-rufrolineatus: 5 rufiolineatus, the expectation being 5.5 of each. A pair of the $F_{2}$ extracted rufrolineatus were inbred and gave in $F_{3} 100 \%$ rufrolineatus. These were again inbred, as a group culture, and gave in $F_{4} 100 \%$ rufrolineatus.

Two pairs of the $F_{1}$ lenconotus-luteolineatus $(B E)$ were mated, one pair in each of two cages. Pair (a) gave 32 lenconotus: 53 lenconotusluteolineatus $(B E): 17$ luteolineatus, and pair $(b)$ produced 33 leuconotus : 48 leuconotus-luteolineatus : 20 luteolineatus, both cages giving totals of 65 leuconotus: 101 leuconotus-huteolineatus : 37 huteolineatus, the expectation being $50 \cdot 75: 101 \cdot 5: 50 \cdot 75$, respectively (Table II $(b)$, $\left.H_{2}\right)$.

Three males and three females of these $F_{2}$ leuconotus-luteolineatus $(B E)$ individuals were inbred, as a group culture, under very unfavourable 


\section{Inheritance and Evolution in Orthopterce I}

conditions and they gave in $F_{3}^{\prime} 8$ lenconotus : 19 leuconotus-luteolineatus : 6 luteolineatus, the expectation being $8.25: 165: 8.25$, respectively. One of the luteolineatus $F_{2}$ males (Table II $(b), F_{2}$ ) was mated to a virgin female of the same apparent constitution but whose pedigree is not known, and they gave in $F_{1} 100 \%$ luteolineatus.

(c) The other luteolineatus-r'ufrolineatus $\left(E F^{\prime}\right)$ heterozygous male (Table II $(a), F_{1}$ ) was mated to an extracted homozygous leucothorax $(C)$ female from a culture whose parents were both leuconotus-leucothorax $(B C)$ heterozygous individuals (Table $\mathrm{I}, F_{\mathrm{f}}, C^{\prime}$ ). (This female was a sister of the leuconotus female parent in mating $(b)$ of this experiment.) They produced the following $F_{1}$ progeny: leucothoraxrufrolineatus $(C F) 17$ : leucothorax-luteolincatus 21, the expectation being 19 of each kind (Table II $(c), F_{1}$ ). The behaviour of this $E F$ male when mated to a homozygous leucothorax female was exactly the same as that of his brother when mated to a homozygous leuconotus female. Both behaviours reveal the constitution of the males, as well also as that of the females.

The inbreeding of these $F_{1}$ leucothorax-rufrolineatus $\left(C F^{\prime}\right)$ and leucothorax-luteolineatus $(C E)$ individuals, respectively, gave $F_{2}$ results as follows: two pairs of leucothorax-rufrolineatus $(C F)$ were inbred, a pair in each of two cages. The pair in cage $(a)$ produced 7 leucothorax : 13 leucothorax-rufrolineatus $(C F): 4$ rufrolineatus, and the pair in cage $(b)$ gave 17 leucothorax : 48 leucothorax-rufiolineatus $(C F): 25$ rufrolineatus; both pairs giving a total of 24 lencothorax : 61 leucothorax-rufrolineatus $(C F): 29$ rufrolineatus, the expectation being $28 \cdot 5: 57: 28 \cdot 5$, respectively (Table II $(c), F_{2}$ ).

The leucothorax-luteolineatus $(C E)$ were inbred, one pair in each of two cages. Pair $(a)$ produced 12 leucothorax : 12 leucothorax-luteolineatus $(C E): 3$ luteolineatus, and pair $(b)$ gave 10 leucothorax : 41 leucothorax-luteolineatus $(C E): 16$ luteolineatus; both pairs producing totals of 22 leucothorax : 53 leucothorax-luteolineatus $\left(C E^{\prime}\right): 19$ luteolineatus, with the expectation of $23.5: 47: 23.5$, respectively (Table II $\left.(c), F_{2}\right)$.

These $F_{2}$ leucothorax-luteolineatus $(C E)$ were inbred under exceptionally unfavourable circumstances, 1 male $\times 1$ female, and they gave in $F_{3} 8$ leucothorax : 6 leucothorax-luteolineatus : 3 luteolineatus, the expectation being $4 \cdot 25: 8 \cdot 5: 4 \cdot 25$, respectively. A pair of these $F_{3}$ leucothorax-luteolineatus individuals were inbred, and after great mortality, gave in $F_{4}, 4$ leucothorax: 1 leucothorax-luteolineatus $(C E)$ : 2 luteolineatus, the expectation being $1 \cdot 75: 3 \cdot 5: 1 \cdot 75$, respectively. 
(3) The interbreeding of heterozygotes.

Experiment III. All the crosses of heterozygous individuals with homozygous ones and the inbreeding of heterozygous ones had given results that could hardly be interpreted in any other way than by assuming that the heterozygous, or hybrid, individuals gave gametes alternatively, one representing the male parent and the other the female parent. Not a single exception to this rule had been noted. A few crosses had been made between different heterozygotes from nature whose constitutions were not ascertained till their $F_{1}$ and $F_{2}$ progeny gave the clue (Exp. I, Table I, and Exp. II (a), (b), (c), Table II $(a),(b),(c))$. At this time it seemed that some crosses ought to be made between different hybrids of known constitutions; so the following crosses were made simultaneously:

(a) A leucothorax-luteolineatus $(C E)$ male from Exp. II (c), $F_{1}$ (Table II $(c), F_{1}$ ) and a leuconotus-leucothorax $(B C)$ female from Exp. III $(c), F_{1}$ (Table IV $\left.(c), F_{1}\right)$ were crossed, and they gave in the $F_{1}$ generation $\left(F_{1}\right.$, Table III $\left.(a)\right)$ :

\begin{tabular}{|c|c|c|c|c|c|}
\hline & & $\begin{array}{l}\text { Leucothorax } \\
\qquad(C)\end{array}$ & $\begin{array}{l}\text { Lemoonotus- } \\
\text { lemeothorax } \\
\qquad B C\end{array}$ & $\begin{array}{l}\text { Teucothorax- } \\
\text { luteolineatus } \\
\text { (OE) }\end{array}$ & $\begin{array}{l}\text { Tutuonotus- } \\
\text { luteolineatus } \\
\quad(B E)\end{array}$ \\
\hline Actual Numbers & $\ldots$ & 9 & 9 & 7 & 13 \\
\hline Expectation & $\ldots$ & $9 \cdot 5$ & $9 \cdot 5$ & $9 \cdot 5$ & $9 \cdot 5$ \\
\hline
\end{tabular}

TABLE IIT.

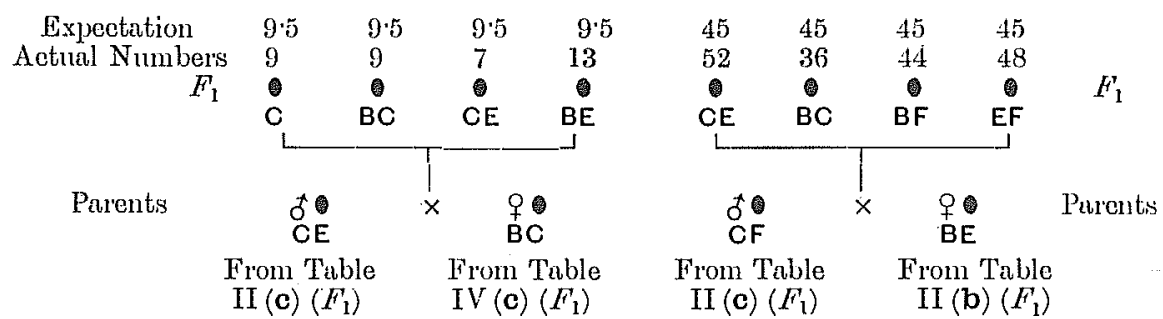

(a)

(b)

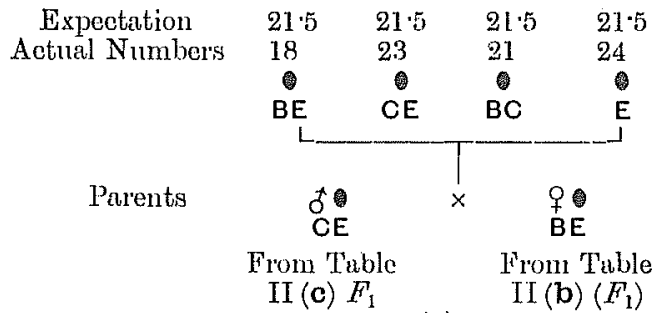

(c)

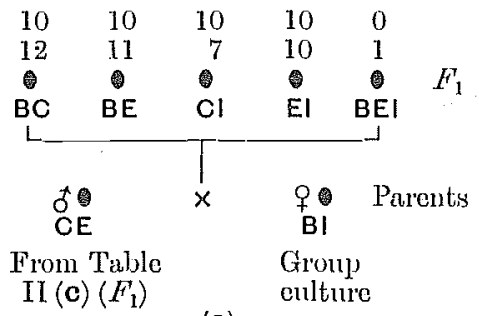

(e)

$$
\begin{array}{ccc}
\mathrm{B}=\text { leusonotus. } & \mathrm{C}=\text { leucothorax. } & \mathrm{E}=\text { luteolineatus. } \\
\mathrm{F}=\text { rufrolineatus. } & \mathrm{I}=\text { nigronotatus. }
\end{array}
$$




\section{Tnheritance and Fotution in Orthoptera I}

(b) A lencothorax-rufrolineatus $\left(C F^{\prime}\right)$ male from $\operatorname{Exp}$. II $(c), F_{1}$ (Table II $(c), F_{1}$ ) was mated to a lenconotus-huteolineatus $(B E)$ female from Exp. II $(b), F_{1}$ (Table II $(b), F_{1}$ ) and the resulting $\not_{1}$ progeny were as follows $\left(F_{1}\right.$, Table IIT $\left.(b)\right)$ :

$\begin{array}{lccccc} & & \begin{array}{c}\text { Lencothorax- } \\ \text { luteolineatns } \\ (C E)\end{array} & \begin{array}{c}\text { Lenconotus- } \\ \text { leucothorax } \\ (B C)\end{array} & \begin{array}{c}\text { Leuconotus- } \\ \text { rufrolineatus } \\ (B F)\end{array} & \begin{array}{c}\text { Luteolinentus- } \\ \text { rufrolineatus } \\ (E F)\end{array} \\ \text { Actinl Numbers } & \ldots & 52 & 36 & 44 & 48 \\ \text { Lxpectatiou } & \ldots & 45 & 45 & 45 & 45\end{array}$

(c) A lencotholax-luteolineatus $(C E)$ male from Exp. II (c), $F_{1}$ (Table II $(c), F_{1}$ ) was crossed with a leuconotus-luteolineatus $(B E)$ female from Exp. II $(b), F_{1}$ (Table II $(b), F_{1}$ ) and they gave in the $F_{1}$ generation (Table III $\left.(c), F_{1}\right)$ :

\begin{tabular}{|c|c|c|c|c|c|}
\hline & & $\begin{array}{l}\text { Leugonouss- } \\
\text { luteolineatus } \\
\qquad(B E)\end{array}$ & $\begin{array}{l}\text { Leucothorix- } \\
\text { luteolineatus } \\
\text { (CE) }\end{array}$ & $\begin{array}{l}\text { Leuconotins- } \\
\text { letcothorix } \\
\qquad(B C)\end{array}$ & $\begin{array}{l}\text { Luteolinentins } \\
(E)\end{array}$ \\
\hline Actral Nirmber's & $\ldots$ & 18 & 23 & 21 & 24 \\
\hline Expectation & $\ldots$ & $21 \cdot 5$ & $21 \cdot 5$ & $21 \cdot 5$ & $21 \tilde{3}$ \\
\hline
\end{tabular}

(d) A lenconotus-luteolineatus $(B E)$ male from $\operatorname{Exp}$. IT $(b), F_{\mathrm{a}}$ and a female lenconotus-lencothorax $(B C)$ from Exp. III $(e), F_{1}$ were mated and they gave in the $F_{1}$ generation the following progeny:

$\begin{array}{llcccc} & & \begin{array}{c}\text { Leuconotus } \\ (B)\end{array} & \begin{array}{c}\text { Leuconotus- } \\ \text { leucothorax } \\ (B C)\end{array} & \begin{array}{c}\text { Leucothorax- } \\ \text { luteolineatus } \\ (C E)\end{array} & \begin{array}{c}\text { Leuconotus- } \\ \text { luteolineatus } \\ (B E)\end{array} \\ \text { Actinal Ninmbers } & \ldots & 7 & 7 & 9 & 6 \\ \text { Expectation } & \ldots & 7 \cdot 25 & 7 \cdot 25 & 7 \cdot 25 & 7 \cdot 25\end{array}$

This experivent, $(d)$, was carried on subsequently to $(c)$ which is the next experiment in this series to be described.)

The results from these crosses gave nothing new. They can be accounted for clearly by assuming that the parent heterozygotes gave gametes alternatively for each parent type of which they were composed and that in fertilization these gametes met by chance. Considering the small numbers, it seems that the approximations to the expectations of alternative inheritance are fairly close. However, the next cross $(e)$ in this series is not so regular.

(e) A lencothorax-huteolineatus (CE) male from Exp. II $(c), B_{1}$ (Table II $\left.(c), F_{1}\right)$ was mated to a lenconotus-uigronotatus $(B I)$ female from a cross between an extracted leuconotiss $(B)$ male and a nigronotatus (Plate VI, Fig. 9) female from nature. This lenconotus-nigronotatus female had the exact appearance of many other heterozygons 
leuconotus-nigronotatus $(B I)$ individuals that have since been produced. Their $F_{1}$ progeny was as follows (Table III $\left.(e), F_{1}\right)$ :

\begin{tabular}{|c|c|c|c|c|c|}
\hline & $\begin{array}{l}\text { Lenconotus- } \\
\text { leuethorax } \\
(B C)\end{array}$ & $\begin{array}{l}\text { Leueonotng- } \\
\text { luteollinerdus } \\
\left(B E^{\prime}\right)\end{array}$ & $\begin{array}{l}\text { Leicothorax- } \\
\text { nigronotatug } \\
(C I)\end{array}$ & $\begin{array}{l}\text { Luteolineatus- } \\
\text { nlgrongotatus } \\
\text { (EI) }\end{array}$ & $\begin{array}{l}\text { Ieuconotus- } \\
\text { luteolineatus. } \\
\text { nigronotatutus } \\
(B E I)\end{array}$ \\
\hline Actual Numbers & 12 & 11 & 7 & 10 & 1 \\
\hline pectation & $12 \cdot 25$ & $12 \cdot 25$ & $12 \cdot 25$ & $12 \cdot 25$ & 0 \\
\hline
\end{tabular}

This result is perfectly regular in every respect, except for the appearance of the leuconotus-luteolineatus-1igronotatus $(B E I)$ individual. 'This specimen was obseryed during its second instar' when its characters were perfectly distinct, and it was kept under close observation until it became adult. The pattern was distinct at all times, but was strikingly clear just after moults. Unfortunately it escaped while the culture was being transferred from the University of Chicago to the Kansas Strate Agricultural College, at Manhattan, in September, 1910. It seems that the production of this aberrant individual may be accounted for by assuming that the leuconotusnigronotatus $(B I)$ female parent gave at least one gamete containing the factors for the patterns of both of her parents and that this double character gamete was fertilized by one of the luteolineatus $(E)$ gametes which came from the leucothorax-luteolineatus $(C E)$ male'.

(4) Further hybridization and inbreeding of the resulting heterozygotes.

Experiment $I V$. The following are additional data concerning the simple crossing of forms where the composition of one of the parents was known and that of the other parent unknown.

(a) A male nigronotatus (Plate VI, fig, 9), from nature, whose pedigree was not known, and a female leuconotus, from the $F_{2}$ generation of a pure leuconotus culture, were crossed, and they gave in $F_{1}$ ten adults, all leuconotus-nigronotatus $(B I)$ heterozygotes (Table IV $(a), F_{1}$ ). A pair of these were inbred and gave in $F_{2}$ three types as follows (Table IV. $\left.(a), F_{2}^{\prime}\right)$ :

$\begin{array}{llccc} & & \begin{array}{c}\text { Leuconotus } \\ (B)\end{array} & \begin{array}{c}\text { Leuconotus. } \\ \text { nigronotatus } \\ (B I)\end{array} & \begin{array}{c}\text { Nigronotatus } \\ (I)\end{array} \\ \text { Actnal Numbers } & \ldots & 3 & 13 & 5 \\ \text { Expectation } & \ldots & 5.25 & 10.5 & 5 \cdot 25\end{array}$

1 In snbsequent experiments-tlie production of an individual with the patterns of three of its ancestors combined-has been repeated fonr times with other combinations of patterns. I now have leuconotns-rufrolineatus-melanothorax $(B F G)$, leucothorax-rufrolineatus-melanothorax (CFG), leuconotus-lencothorax-melanothorax (BCG), and rnfrolineatus-melanothorax-lenconotatus $(F G J)$ (the leuconotatus $(J)$, a new form to be described later). These have now been bred for some time, some of them to the $F_{1}$ generation. Their inheritance behavionr will be reported soon in anotlser acconnt.

Journ. of Gen. III 


\section{Inheritance and Evolution in Orthoptera I}

These were bred further as follows: a male leuconotus was mated to a sister leuconotus-nigronotatus $(B I)$ female, and they gave in $F_{3}$ the following progeny:

\begin{tabular}{|c|c|c|c|}
\hline$J$ & & $\begin{array}{l}\text { Lenconotus } \\
\text { (B) }\end{array}$ & $\begin{array}{c}\text { Lenconotus- } \\
\text { ulgrouotatus } \\
(D I)\end{array}$ \\
\hline Actual Numbers & $\ldots$ & 4 & 6 \\
\hline Bxpectation & $\ldots$ & 5 & 5 \\
\hline
\end{tabular}

TABLE IV.

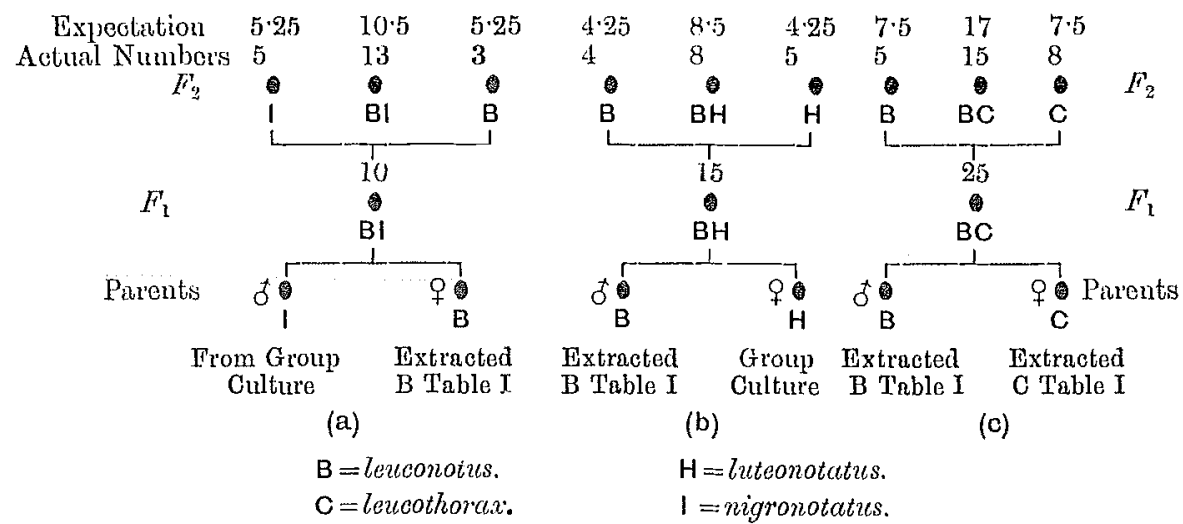

These $F_{3}$ leuconotus-nigronotatus $(B I)$ were inbred, 1 male $\times 2$ females, and they gave in $F_{4}$ the three following types:

$\begin{array}{lccccc} & & \begin{array}{c}\text { Leuconotus } \\ (I 3)\end{array} & \begin{array}{c}\text { Leuconotus- } \\ \text { nigronotatus } \\ (D I)\end{array} & \begin{array}{c}\text { Nigronotatus } \\ (I)\end{array} & \\ \text { Actual Numbers } & \ldots & 9 & 30 & 13 & F_{4} \\ \text { Expectation } & \ldots & 13 & 26 & 13 & \end{array}$

(b) A male leuconotus $(B)$, from the $F_{2}$ generation of a pure leuconotus culture, and a female luteonotatus $(H)$, whose parents had been taken from nature, were mated, and their $F_{1}$ progeny were all distinctly marked leuconotus-luteonotatus heterozygotes (Table IV $(b)$, $\left.F_{1}\right)$. Two males and two females of these were inbred and, after great mortality, they gave in $F_{2}$ the following progeny (Table IV $(b), F_{2}$ ):

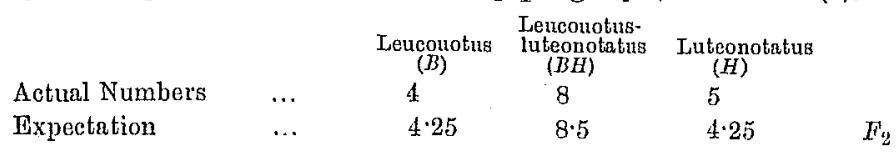

These results, as in the other cases (Exp. II $(a),(b),(c)$ ), give the clue to the composition of the unknown first parent in each case, proving them to have been homozygous nigronotatus $(I)$ and luteonotatus $(H)$, respectively. 
(c) In order to try out more completely the behaviour of the heterozygotes derived from the crossing of leuconotus and leucothorax, a leuconotus male from the second generation of an extracted leuconotus culture (Exp. I, $F_{3}$ ) was mated to a leucothorax female from the second generation of an extracted leucothorax culture $\left(\operatorname{Exp} . \mathrm{I}, F_{3}\right)$. The $F_{1}$ result was twenty-five adults, all leuconotus-leucothorax $(B C)$. These leuconotus-leucothorax heterozygotes were inbred and gave in $F_{2}$ the following progeny (Table IV $(c), F_{1}$ ):

$\begin{array}{lccccc} & & \begin{array}{c}\text { Letconotus } \\ (B)\end{array} & \begin{array}{c}\text { Leuconotus- } \\ \text { leucothorax } \\ (B C)\end{array} & \begin{array}{c}\text { Leucothornx } \\ (C)\end{array} \\ \text { Actual Numbers } & \ldots & 5 & 17 & 8 & F_{2} \\ \text { Expectation } & \ldots & 7 \cdot 5 & 15 & 7 \cdot 5 & \end{array}$

This result is in perfect accord with the other results, showing that the first parents were homozygous; and that the $F_{1}$ heterozygotes behaved in a regular Mendelian manner just as did the exactly similar leuconotus-leucothorax $(B C)$ heterozygotes in Exp. I.

(5) Results from the mating of heterozygous individuals with one or the other of their homozygous parent forms.

Experiment $V$. (a) A leuconotus-lencothorax (BC) male from Exp. I, $F_{3}$ (Table I, $F_{3}$ ) was mated to a leuconotus $(B)$ female sister, and they gave in $F_{1}\left(F_{4}\right)$ the following results (Table $V$ ):

$\begin{array}{lcccc} & & \begin{array}{c}\text { Leuconotus- } \\ \text { leucothorax } \\ (B C)\end{array} & \begin{array}{c}\text { Lenconotus } \\ (C)\end{array} & \\ \text { Actual Numbers } & \ldots & 20 & 20 & F_{1}\left(F_{4}\right) \\ \text { Expectation } & \ldots & 20 & 20 & \end{array}$

TABLE V.

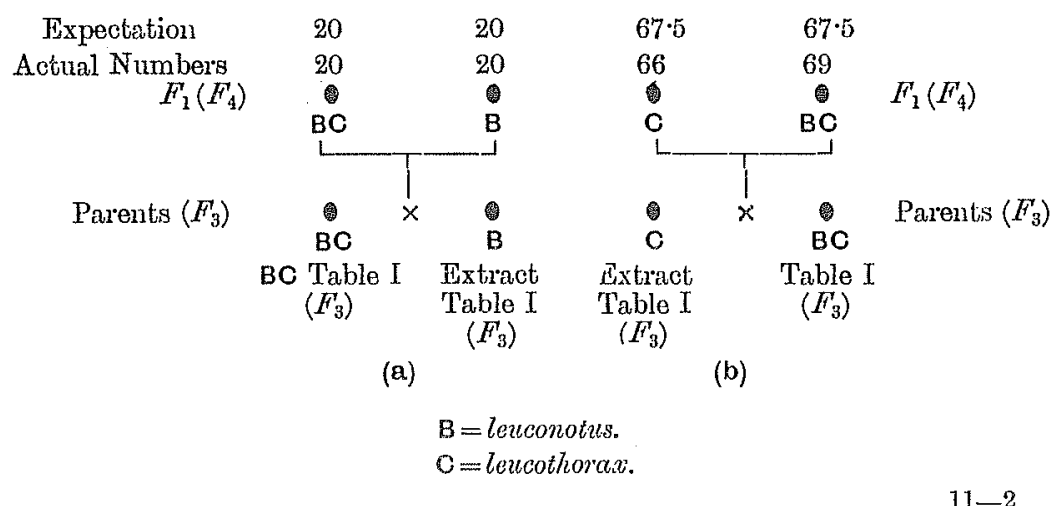




\section{Inheritance and Evolution in Onthoptera I}

(b) A leuconotus-leucothorax male from Exp. I, $F_{3}$ (Table I, $F_{3}$ ) and a sister leucothorax $(O)$ were mated and their $F_{1}\left(F_{4}\right)$ progeny were as follows:

$\begin{array}{llccc} & & \begin{array}{c}\text { Lenconotus- } \\ \text { lencotlongax } \\ (B C)\end{array} & \begin{array}{c}\text { Leucothorax } \\ (C)\end{array} & \\ \text { Actual Numbers } & \ldots & 69 & 66 & F_{1}\left(F_{4}^{\prime}\right) \\ \text { Expectrtion } & \ldots & 67.5 & 67.5 & \end{array}$

These results are typically Mendelian, and close the report to be macle at this time on the inheritance of colour patterns.

\section{LONG AND SHORT WINGEDNESS.}

(1) Long and short wingedness in Nature.

It is a matter of common observation that in many species of the Acridiidae and Gryllidae there is dimorphism or polymorphism in the length of the wings-some of the members bearing short and others long wings (In the Tetriginae, unless otherwise indicated, the word wingedness refers to pronotum also.) The differences in some cases have been considered by systematists sufficient to justify the giving of different varietal names to the two forms (e.g. Tettigidea parvipennis, Morse, and Tettigidec parvipennis pennata, Morse, the short and long winged forms of $T$. pennatus) (4).

The studies of the difference in lengths of the wings in the Acrididae have been, so far as I can ascertain, confined to the field observations and to the examination of collections in museums. However, in the Gryllidae, Lutz (1907) has made observations concerning this phenomenon of long and short wingedness (pronotum not considered) in a breeding experiment with Gryllus sp. His results brought him to the conclusion that the length of the wings of the species with which he worked was not conditioned by heredity, but by the environmental conditions under which the individuals grew to maturity (6).

In the Tetriginae, the differences in the length of the wings and pronota are usually, though not invariably, dimorphic; several variations from the long and short winged forms have been found, and some individuals were strictly intermediate between the two extremes. It is the usual occurrence to find a long pronotum with long wings and a short pronotum with short wings, but a few variations from this rule have occurred as follows: in a few instances long wings have accompanied a short pronotum, and one individual exhibited a short pronotum with one wing long and the other short (the various types are shown in Fig. 2). 


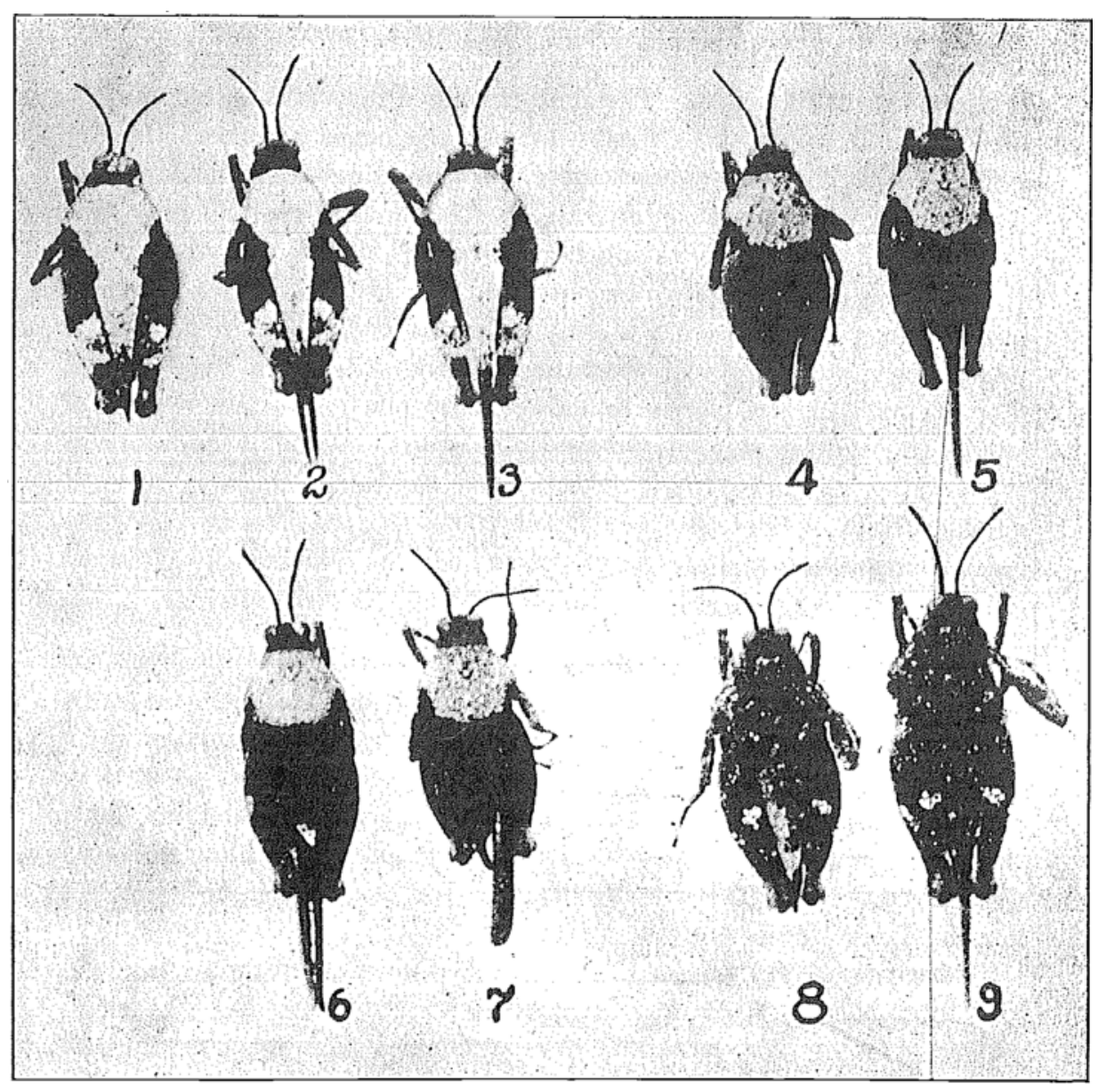

Fig. 2.

1, 2, 3, Brothers from the same eage.

4, 5, Brothers.

6, Short pronotum, both wings long.

7, Short pronotum, one wing long.

8, 9, Sisters.

All on the same seale. 
In the vicinity of Chicago, the genus Tettigidea is found to be about equally divided between the long and short winged individuals. They are almost strictly dimorphic. The genus Tettix exhibits polymorphism in respect to this character, running all the way from extreme short to extreme long wingedness. The shorter winged individuals predominate in this genus, while the extreme long winged ones are rare. In the genus Paratettix, Bol., under more particular consideration in this paper, long wingedness is the rule in the Chicago region-only two short winged individuals having been observed among many hundreds. In Arkansas, a few short winged individuals were found among several hundred long winged ones, while in Louisiana and Southern Texas, the two forms, practically without intermediates, existed in about equal proportions. In the North, in nature, only one generation a year of any of the species is produced and the growth period is normally in the late spring and early summer when the adult stage is reached quickly, while in Louisiana and Texas Paratettix produces two or three generations a year; and the growth period continues practically throughout the year, with the optimum in the spring and early summer.

(2) Long and short wingedness in the breeding experiments.

The observation on the occurrence of long and short winged forms during the breeding experiments will be reported at this time only for the individuals maturing in the inheritance of the colour pattern in Exp. I (Table I). In that experiment the wing length of the individuals was not considered just as in the following account the colour patterns are not considered, there being no apparent correlation between the length of the wingss and the pattern.

Referring to the diagram (diagram II), the first mating was made in September 1908 between one short winged male and two short winged females. At least one of the females was not virgin. The $F_{1}$ generation which hatched in December matured after great mortality the following March and April in these proportions:

Long winged 17 : Short Winged $15\left(F_{1}\right)$.

The short winged individuals, inbred, produced progeny which hatched in May and became adult in July and August in the following ratio:

Long Winged 224: Short Winged $7\left(F_{2}\right)$.

These $F_{2}$ short winged individuals, inbred, produced progeny in September, which, after great mortality: matured the next March and all were short winged. 
Going back to the long winged forms from the inbreeding of the $F_{1}$ generation short winged, their progeny which hatched in August matured from December to February:

Long Winged 20 : Short Winged $8\left(F_{3}\right)$.

These last short winged did not produce progeny until the following March and they grew from March to June resulting in:

Long Winged $10\left(F_{4}\right)$.

The $F_{1}$ generation long winged gave progeny which hatehed in May and becane adult in June and July and were:

Long Winged 336 : Short Winged $4\left(F_{2}\right)$.

\section{DIAGRAM II.}

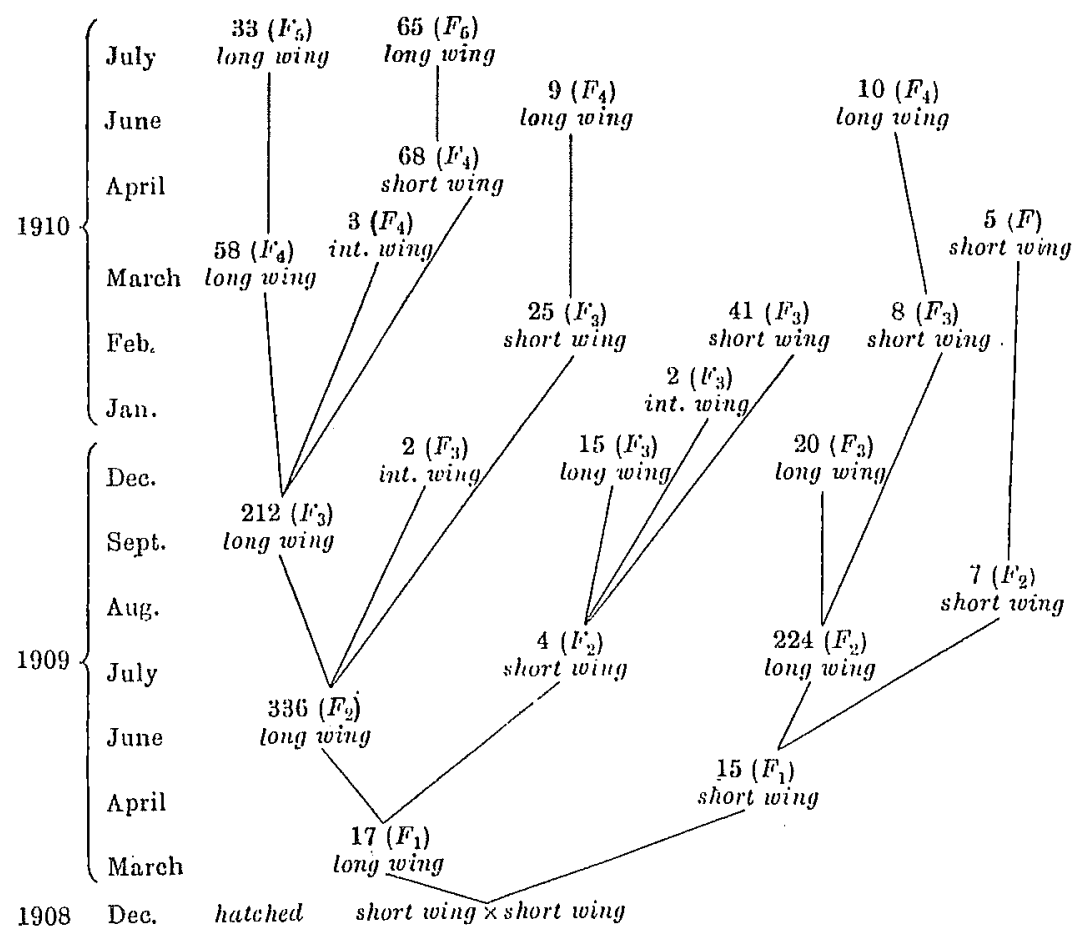

This is nearly the same result as that obtained from the inbreeding of the $\mathscr{W}_{1}$ generation short winged brothers and sisters. From the inbreeding of the short winged of this last fraternity, progeny were 


\section{Inheritance and IVolution in Orthoptera I}

hatched in August which matured from December to February and gave :

Long Winged 15 : Intermediate Winged 2 : Short Winged $41\left(F_{\mathrm{a}}\right)$.

Now going back to the long winged of generation $F_{2}$, long winged, their inbreeding gave progeny in July which matured from September to February :

Long Winged 212 : Intermediate Winged 2 : Short Winged $25\left(F_{3}\right)$.

The long winged in this instance were nearly all matured by the end of September, while the intermediate and short winged required until February to mature. The short winged ones just enumerated as maturing in February, produced young in March, which matured in June:

$$
\text { Long Winged } 9\left(F_{4}\right) \text {. }
$$

The inbreeding from the long winged of $F_{3}$ generation progeny produced young in October which matured the following March and April :

Long Winged 58 : Intermediate Winged 3 : Short Winged $68\left(F_{4}^{\prime}\right)$. These short winged gave young in April which matured in July:

Long Winged $65\left(F_{5}\right)$.

Their long winged brothers and sisters, generation $F_{4}$, also produced young in April which matured in July:

$$
\text { Long Winged } 33\left(F_{5}\right) \text {. }
$$

\section{AN EXamination OF THE LOCATION, aRrangement, aND RELA- TTONS OF THE PIGMENTAL ELEMENTS IN THE COLOUR PATTERNS OF THE EXTRACTED SPECIES AND THEIR HYBRIDS.}

All the hybrids thus far produced, except some of those in which texanus $(A)$ is a component, exhibit, on superficial examination as shown in the photographs, the colour character, or part of it, of each of the components. In some cases, as leuconotus-leucothorax $(B C)$, leuconotus-melanothorax $(B G)$, and leucothorax-melanothorax $(C G)$, on superficial examination the elements of the parents appear to be present in apparently equal proportions, while in others, as leuconotus nigronotatus $(B I)$, leuconotus-luteonotatus $(B H)$, leucothorax-nigronotatus $(C I)$, leucothorax-luteonotatus $(C H)$, leuconotus-rufrolineatus $(B F)$, leuconotus-luteolineatus $(B E)$, leucothorax-rufrolineatus $\left(C F^{\prime}\right)$, and 
leucothorax-luteolineatus $(C E)$, the characters of the leuconotus $(B)$ and leucothorax $(C)$ parents appear to obscure or replace the brown or mottled brown parts of the characters of nigronotatus $(I)$, luteonotatus $(H)$, rufrolineatus $\left(F^{\prime}\right)$, and luteolineatus $(E)$, respectively, and allow only their more brilliant parts (mahogany brown, yellowish red, and dense black) to appear (Plate VI). It was first thought that these more brilliant parts (mahogany brown, yellowish red, or dense black) were separated, in the patterns of the hybrids, from the grays or mottled brown parts which accompanied them in the patterns of the parent species. In order to test this matter more definitely than a superficial examination of the patterns allows, sections have been made through the pronota of several of the hybrids and their parent species and these

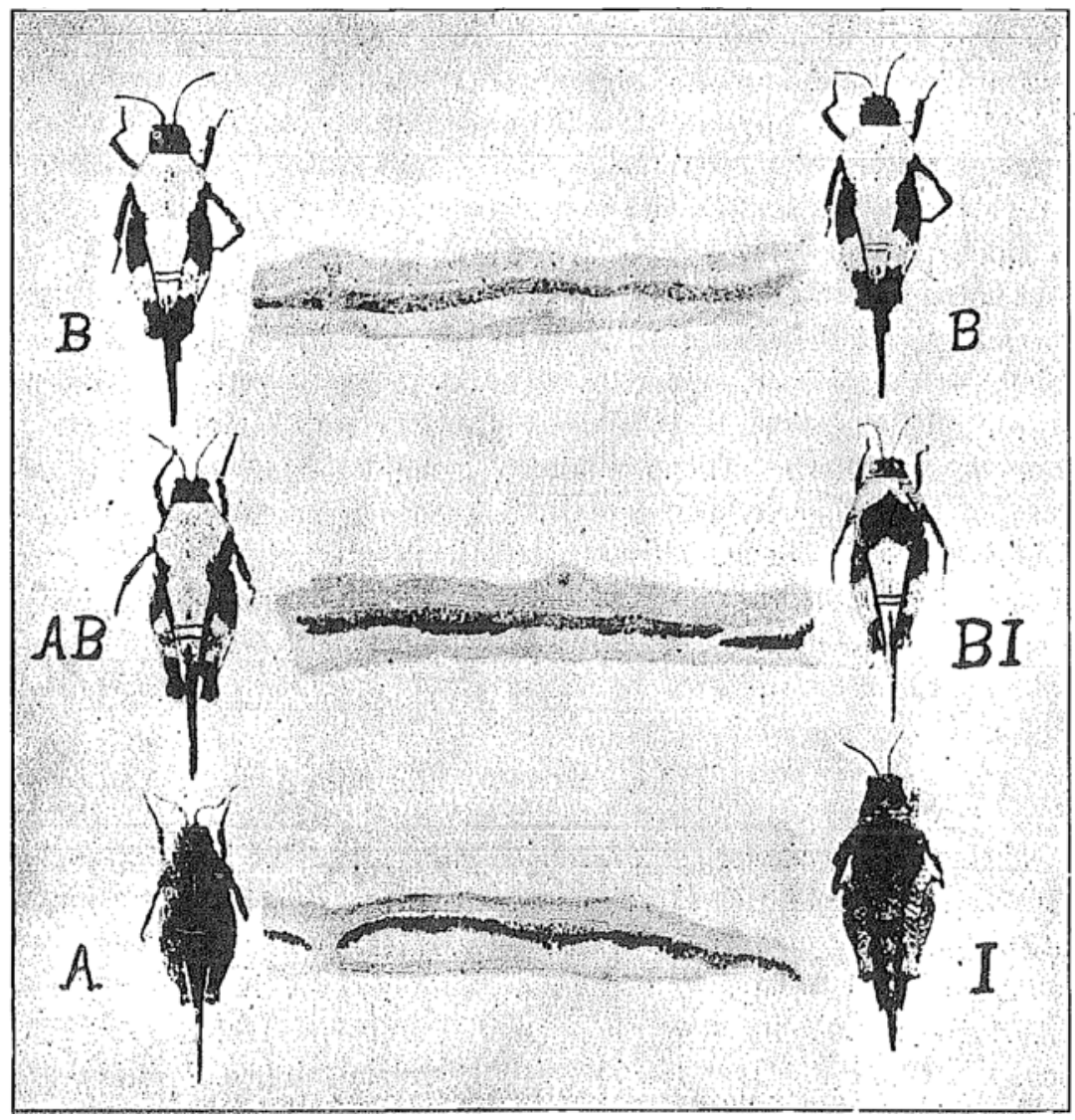

Fig. 3. 
examined microscopically. The examination of the section through the pronotum of nigronotatus $(I)$, about midway between the deep black spot and the posterior end of the pronotum, reveals a deeply pigmented hypodermis with the cuticle somewhat brown in places (Fig. 3, I). The examination of a section of leuconotus $(B)$ from approximately the same location as the one taken from nigronotatus $(I)$ (Fig. $3, B$ ) shows the hypodermis to be practically without pigment and the cuticle colourless. A section from approximately the same part of the pronotum of leuconotus-nigronotatus $(B I)$ (Fig. 3, $B I$ ) reveals a nearly clear cuticle with about one-half as much hypodermal pigment as is found in nigronotatus $(I)$. The situation regarding pigmentation in the pronotum of texanus and the hybrid from it and leuconotus $(B)$ appenrs to be exactly the same as that for nigronotatus $(I)$, leuconotus $(B)$ and their hybrid lenconotus-nigronotatus (BI). In the figure (Fig. 3) texanus is placed opposite nigronotatus, and the lenconotus-texanus hybrid is placed opposite the leuconotus-nigronotatus $(B I)$ hybrid, although the drawings were made from the specimens first described.

This study reveals the fact that the character of nigronotatus $(I)$ is as much present in this posterior part of the pronotum of the hybrid leuconotus-nigronotatus $(B I)$, as the more advantageously displayed leuconotus $(B)$, though the latter when the hybrid is scrutinized superficially, is the only one apparent. The same proportions and relations in the pigmentation of texanus and the heterozygote, leuconotustexanus, are shown. The preliminary examination of the pronota of some of the other hybrids and their parent forms reveals a similar situation. The evidence indicates that the peculiar pigmental elements of each of the patterns of the pronota of the parents are present in the pronotum of their hybrid in about equal proportions.

\section{Discussion,}

(1) The inheritance of the colour patterns. The inheritance behaviour throughout the experiments, with five exceptions (leuconotusluteolineatus-nigronotatus ( $B E I$ ) Table III (e)), and four others now being bred and to be described later, fulfils very nearly the Mendelian expectations. Among more than 5000 recorded individuals resulting from the crossing of species, inbreeding and crossing of hybrids, and the crossing of hybrids with species, and more than 2000 recorded progeny from the inbreeding of species, only the five unexpected 
individuals appeared, and the expectations in regard to the proportionate numbers have been fairly realized.

The Mendelian assumption that hybrids do not produce gametes representing themselves, but give gametes of the species from which they themselves were formed and that these gametes are produced alternatively in about equal proportions, accounts, with the five exceptions, for all the results which have come from my breeding experiments with the grouse locusts.

In Exps. I $\left(F_{2}-\right)$, II $(b)$ and $(c)$, III $(a),(b),(c),(d)$, and $V(a),(b)$, the ancestry of the parents used was known for one or more generations, and their resulting progeny, in the matter of patterns completely (with the five exceptions in thousands), and in the matter of proportionate numbers, fairly, approximated to the expectations of alternative inheritance. As the results from known parents are closely approximate to expectation, it seems reasonable to expect the equally regular and similar results from parents whose ancestry was not known at first to lead to the identification of the constitution of the parents themselves. It has been by this method that the constitutions of the parents from the field and group cultures used in Exps. I, II, and IV have been determined.

(2) The appearance of long and short wingedness. A glance at the behaviour of the wing lengths character shows that the short winged required the maximum of time to reach maturity after hatching, and that this great length of time is closely correlated with the time of the year-the fall and winter months. The long winged individuals on the other hand required a minimum of time to reach maturity after hatching, and this minimum time is also closely correlated with the time of the year-the spring and early summer. 'The time of the year during which growth proceeds seems to determine whether it shall extend over a long period or not. If the time for growth be a long one the wing lengths are likely to be short; if the time required for growth be a short one the wing lengths are likely to be long. The length of the wings of the parents does not condition this character in the progeny. The progeny of short winged individuals become long winged if they grow quickly in the spring. The progeny of the long winged individuals become short winged if the growth take place slowly during a long time. Long winged individuals may produce a majority short winged if the growth take place from October to April, while their brother and sister short winged ones may produce all long winged, if the growth progress from March to June. Nor does 
the phenomenon appear to be due to an inherited seasonal rhythm; for the fourth generation progeny, coming from the short winged generation IIT, which had grown from July to February, the time required for two generations of their brother and sister generation II and ITI progeny, behaved exactly as the progeny $F_{5}$ of the long winged and short winged which had come from the fourth generation of the same line.

(3) Equivalence in the hybrids. From the examination of the pigmental composibions of the colour patterns of the pronota so far as it has progressed, the conclusion seems to be justified that the peculiar pigmental elements of each of the patterns of the pronota of the parents are present in the pattern of the pronotium of their hybrid in about, if not in exactly, equal proportions. With this knowledge in mind it does not appear that the terms dominant and recessive are applicable at all to these grouse locusts; they appear to be, in respect to their representation in the composition of their hybrids, perfectly equivalent, or, to use Davenport's term, equipotent (2). If only the superficial appearances be taken into consideration, Bateson's terms of epistatic, for the colour most apparent, and hypostatic, for the colour less apparent, may be employed in some instances (1.).

The fact that the heterozygote pattern in the end result is so equivalently made up of the respective patterns of the parent species seems to warrant the suggestion that the somatic part of the hybrid zygote (fertilized hybrid ovum) in its somatogenesis may be in some way alternative, giving the character of the one, and then the character of the other, parent to the resulting soma of the hybrid; just as the gametal part of this same hybrid zygote in its gametogenesis is usually most certainly altemative, giving a gamete for the one, and then a gamete for the other parent.

(4) The "Genotype Conception." These forms approximately, if not completely, fulfil the requirements of the description of biotypes by Johannsen. The evidence points to the fact that in none of the in heritance behaviour observed is there any transmission of the qualities of the parent to the offspring (5). (There have been five exceptions noted.) The regular $1: 2: 1$ ratio result of the inbreeding of hybrids, the 1 : 1 ratio result of the crossing of hybrids with their parent types, and the $1: 1: 1: 1$ ratio result of the interbreeding of hybrids indicate that the qualities of the parents, as well as the qualities of the progeny, are determined by the nature of the germinal material, and that the 
germinal material of each species is pure and inviolate from generation to generation, whatever the combinations that are made with them. The fact that two germ plasms come together to make a heterozygote does not alter this situation, because, although combined in fertilization into a harmoniously acting zygotic system, they immediately separnte in gametogenesis as though they had not been mixed at all but had been held together only. The resulting soma (the pattern only considered here) indicates that each of the gametes gives the soma characters of its own kind, and that these two sets of characters, from the two parental sources brought together in fertilization, are in a sense dove-tailed one into the other to make the individual heterozygotic combination.

\section{Conclusion.}

The imheritance behaviour of the colour patterns in these orthopterous insects shows clearly the Mendelian type of inheritance, and the essential result of these experiments has been the extension of this principle to a considerable number of types of a phylogenetically low group of ametabolous insects.

All the hybrid patterns, except a few which have not been adequately examined, show plainly in their visible somatic constitution all the parts which can be distinguished in the somatic make-up of each of their parent patterns. No character of one parent species is ever replaced in the $F_{1}$ hybrid by any character of the other parent. All the characters of each parent are represented in the $F_{1}$ hybrid. It follows, then, that these grasshoppers do not exhibit characters, which by crossing cin be replaced by other different characters; the whole pattern appears to be the only unit.

Dimorphism and polymorphism in the length of the wings and pronota are not inheritable, but are somatic, due to variable incident conditions under which the individuals grow. The conditions causing slow growth, extended over several months, produce a preponderance of short winged individuals. These conditions obtain in the fall and winter', and may be a matter largely of the lack of sunshine. The conditions causing quick growth, extended over a shorter time, produce a preponderance of long winged individuals. These conditions obtain in the spring and early summer and may be largely a matter of an abundance of sunshine.

I desire to express my thanks to Prof. W. L. Tower for the use of equipment and for much valuable time given in consultation during the progress of the work and the preparation of the MSS. The late 


\section{Inheritance and Evolution in Orthoptera I}

Prof. C. O. Whitman first suggested the problem and introduced me to Dr J. L. Hancock who has given valuable aid in the Taxonomy and Natural History of the material. To these friends I am grateful for invaluable assistance and encouragement.

\section{EXPLANATION OF PLATE $V \%$}

Most of the photographs are of fellales, the patterns of both males and females being the same. The difference in sizes is not significant, being due to the scale of the photogr'aphs.

The top row represents the true breeding forms. The middle and lower rows repre. sent eighteen of the hetelozygous forms devived from clossing the pure strains. $C G, C I_{1}$ $F F$, and $E H$ ure modified photographs, the patterns of the rest boing untouched or only tinted.

\section{BIBLIOGRAPHY。}

具. 1909. Batmson, W. "Mendel's Principles of Heredity" Cambridge University Press.

2. 1907. Davinnpont, C. B. "Heredity and Mendel's Law." Proceedings of the Washington Academy of Sciences; Vol. IX. p. 179.

3. 1910. Doncastęr, L. "Heredity in the Light of Recent Research." Camblidge University Press.

4. 1902. Hanconk, J. L. "The Tettigidae of North America" Chicago.

5. 1911. Jomannsten, W. "The Genotype Conception of Heredity." American Naturalist, Vol. xuv. No. 531.

6. 1907. Lomz, Frann E. "The Variation and Correlation of the Taxonomio Characters of Gryllus." Carnegie Inst. Pub. 101.

7. 1910. Montgomeny, T. H. "Are Penticular Chromosomes Sex Deterninants?" Biological Bulletin, xIx. No. I, pp. 1-17.

8. 1910. Towse, W. L. "The Determination of Dominance and the Modification of Behaviour in Alternative (Mendelian) Inheritance by Conditions Surrounding on Incident upon the Germ Cells at Fertilization." Biological Bulletin, xvmr. pp. 285-337.

9. 1893. Whrman, C. O. "The Inadequacy of the Cell Theory of Development." Woods Hole Biological Lectures. 